Article

\title{
The Role of Dactylis Glomerata and Diesel Oil in the Formation of Microbiome and Soil Enzyme Activity
}

\author{
Agata Borowik@, Jadwiga Wyszkowska *®D, Mirosław Kucharski and Jan Kucharski® \\ Department of Microbiology, University of Warmia and Mazury in Olsztyn, 10-727 Olsztyn, Poland; \\ agata.borowik@uwm.edu.pl (A.B.); miroslaw.kucharski@sloik.net (M.K.); jan.kucharski@uwm.edu.pl (J.K.) \\ * Correspondence: jadwiga.wyszkowska@uwm.edu.pl
}

Received: 30 April 2020; Accepted: 11 June 2020; Published: 13 June 2020

\begin{abstract}
The global demand for petroleum contributes to a significant increase in soil pollution with petroleum-based products that pose a severe risk not only to humans but also to plants and the soil microbiome. The increasing pollution of the natural environment urges the search for effective remediation methods. Considering the above, the objective of this study was to determine the usability of Dactylis glomerata for the degradation of hydrocarbons contained in diesel oil (DO), as well as the effects of both the plant tested and DO on the biochemical functionality and changes in the soil microbiome. The experiment was conducted in a greenhouse with non-polluted soil as well as soil polluted with DO and phytoremediated with Dactylis glomerata. Soil pollution with DO increased the numbers of microorganisms and soil enzymes and decreased the value of the ecophysiological diversity index of microorganisms. Besides, it contributed to changes in the bacterial structure at all taxonomic levels. DO was found to increase the abundance of Proteobacteria and to decrease that of Actinobacteria, Acidobacteria, Chloroflexi, Gemmatimonadetes and Firmicutes. In the non-polluted soil, the core microbiome was represented by Kaistobacter and Rhodoplanes, whereas in the DO-polluted soil, it was represented by Parvibaculum and Rhodococcus. In soil sown with Dactylis glomerata, gasoline fraction $\left(C_{6}-C_{12}\right)$ degradation was higher by $17 \%$; mineral oil $\left(C_{12}-C_{35}\right)$, by $9 \%$; benzene, by $31 \%$; anthracene, by $12 \%$; chrysene, by $38 \%$; benzo(a)anthracene, by $19 \%$; benzo(a)pyrene, by $17 \%$; benzo(b)fluoranthene, by $15 \%$; and benzo(k)fluoranthene, by $18 \%$ than in non-sowed soil. To conclude, Dactylis glomerata proved useful in degrading DO hydrocarbons and, therefore, may be recommended for the phytoremediation of soils polluted with petroleum-based products. It has been shown that the microbiological, biochemical and chemical tests are fast and sensitive in the diagnosis of soil contamination with petroleum products, and a combination of all these tests gives a reliable assessment of the state of soils.
\end{abstract}

Keywords: PHAs; bacterial taxa; soil enzymes; Dactylis glomerata; phytoremediation

\section{Introduction}

What all organisms need to exist is a continuous flow of energy [1,2]. Some of them derive energy from sun rays while others do so from organic and inorganic compounds [3-5]. This diversity makes them able to convert various pollutants [6], including those contained in petroleum-based products [7], which consequently affects the succession of microorganisms in the natural environment $[6,8]$. Hydrocarbons [7,9-11], heavy metals [12-15] and pesticides [16,17] are a severe threat to the natural environment due to their high accumulation potential and high toxicity in the soil ecosystem [18]. Hydrocarbons can be more easily removed than heavy metals, because they serve as a source of carbon and energy to microorganisms [19,20] and thus can be thoroughly degraded [21-23]. According to Yang et al. [24], Patowary et al. [25], and Bidja et al. [10], the microorganisms able to transform hydrocarbons and, by this means, to remove them from soil include, among others, 
Nocardia soli, Rhodococcus erythropolis, Bacillus pumilus and Bacillus cereus or Serratia marcescens and Raoultella ornithinolytica. According to Obi et al. [26] and Xu et al. [20], bacteria of the following genus may be useful in soil detoxification for PAH: Achromobacter, Arthrobacter, Enterobacter, Klebsiella, Kocuria, Mesorhizobium and Pseudomonas. Essential in the removal process for petroleum-derived hydrocarbons is not only their degradation but also modification of their hydrophobic and hydrophilic properties by biosurfactant-producing microorganisms, e.g., Bacillus methylotrophicus, Bacillus licheniformis, Proteus vulgaris, Proteus mirabilis, Serratia marcescens, Sphingomonas paucimobilis, and Micrococcus kristinae [27,28].

Despite the ability of certain microorganisms to use hydrocarbons as energetic substrates $[20,26]$, these chemicals pose a severe threat to other soil organisms and plants [29], and to the entire trophic chain [30]. Environmental exposure to the effects of various groups of xenobiotics can trigger changes in the functioning of a microbial population [31]. This, in turn, aggravates the threat posed to the optimal functioning of soil ecosystems, especially considering the recently increased environmental pollution [32]. All this has prompted a search for inexpensive methods that would aid the degradation of toxic compounds in soils [33]. One of the most effective methods enabling the counteracting of the effects of soil pollution is bioremediation $[7,8,22,33,34]$, and one of its techniques is phytoremediation [29,35-37]. Cheap and effective technologies for the remediation of contaminated soils are currently in high demand. Biodegradation and phytostabilization are environmentally friendly, and therefore, the search for plants resistant to pollution is justified. The absorption of pollutants by plants, the translocation and accumulation of pollutants, their stabilization in the root zone and the transformation of organic pollutants by rhizosphere microorganisms are extremely valuable [38]. Phytoremediation is considered one of the most environmentally friendly methods. In situ biological methods used for soil reclamation rely on the synergistic interaction of plants and associated microorganisms [29,35-37]. Microorganisms supported by organic plant substrates can contribute to the significant degradation of compounds contained in petroleum substances [19]. Therefore, the search for plants and microorganisms effective in improving the quality of the soil environment poses an essential challenge to science and environmental engineering. They ought to be investigated, considering their function, as they cannot be plants grown for food but rather are useful for energetic purposes $[19,37,39,40]$, e.g., Dactylis glomerata var. Bepro, which was used in our study for the phytoremediation of soil polluted with diesel oil. The goals of this study were to determine the usability of Dactylis glomerata for the degradation of diesel oil hydrocarbons and to investigate the effects of both the plant tested and diesel oil on the biochemical functionality and changes in soil microbiome at various taxonomic levels. The knowledge gained from this study may prove useful in the biotechnology for removing petroleum-based products from the soil, because the potential of plant rhizosphere microorganisms, aided by nutritional substrates produced by plant roots, can significantly contribute to the remediation of soils and polycyclic aromatic hydrocarbon (PAH) degradation.

\section{Materials and Methods}

\subsection{Study Object}

Soil. The study was conducted with Eutric Cambisol soil having the following composition: $74.93 \%$ of sand fraction (grain diameter: $0.05-2 \mathrm{~mm}$ ), 22.85\% of silt fraction (grain diameter: 0.002-0.05 mm), and $2.22 \%$ of clay fraction (grain diameter: $<0.002 \mathrm{~mm}$ ). The soil had high contents of phosphorus (93.68 mg of available $\mathrm{P} \mathrm{kg}^{-1} \mathrm{~d}$.m. soil) and potassium (141.10 mg of available $\mathrm{K} \mathrm{kg}^{-1} \mathrm{~d} . \mathrm{m}$. soil), and a medium content of magnesium (42 mg of available $\mathrm{Mg} \mathrm{kg}^{-1} \mathrm{~d}$.m. soil). It contained $0.62 \mathrm{~g} \mathrm{~N} \mathrm{~kg}^{-1} \mathrm{~d} . \mathrm{m}^{\text {. }}$ soil and $9.30 \mathrm{~g} \mathrm{C}_{\text {org }} \mathrm{kg}^{-1} \mathrm{~d}$.m. soil. Its $\mathrm{pH}$ in $1 \mathrm{~mol} \mathrm{KCl} \mathrm{dm}{ }^{-3}$ was 6.7 , and its exchangeable capacity was $60.40 \mathrm{mmol}(+) \mathrm{kg}^{-1} \mathrm{~d}$.m. soil. The soil was collected from a depth of 0 to $20 \mathrm{~cm}$ of the arable lands from the Olsztyn Lake District situated in the north-east of Poland, within the province of the Eastern Baltic-Belarusian Lowland, which is part of the Eastern European Plain (NE Poland, 53.7161N, 20.4167E). 
Diesel oil. The study was conducted with BP diesel oil (DO) with Active technology, composed of $\mathrm{C}_{10}-\mathrm{C}_{28}$ hydrocarbons (over 90\%) [41]. The choice of this DO was driven by its increasing use in Poland and other EU Member States [42].

Plant. The test plant used for phytoremediation was orchard grass (Dactylis glomerata) of Bepro variety. It is an energy grass characterized by a biomass production of 11 to $13 \mathrm{Mg} \mathrm{d.m}$. ha ${ }^{-1}$. It withstands drought and low temperatures [43], is relatively resistant to diseases [40] and exhibits high capability for adapting to varying weather conditions. Dactylis glomerata is a plant highly resistant to PAH contamination. It shows growth on virtually any type of soil. Its dense bundle root system allows soil penetration over a large area $[19,44,45]$.

\subsection{Study Design}

Because the study assumed the detailed identification of the microbiome of soil polluted with a petroleum-based product, it was performed under strictly controlled conditions in a greenhouse in Kick-Brauckman polyethylene pots. This prevented pollutant migration to the natural environment. The experiment was performed with 4 replications and established in 4 series: (1) non-polluted and non-sown soil (C), (2) non-polluted soil sown with Dactylis glomerata (Dg), (3) non-sown soil polluted with diesel oil (DO), and (4) soil polluted with diesel oil and sown with Dactylis glomerata (DgDO).

The soil was sieved through a screen with a mesh diameter of $1 \mathrm{~cm}$, thoroughly mixed, and transferred to pots. Afterward, its $9 \mathrm{~kg}$ portions were prepared (for each pot), supplemented with the following macroelements, per $1 \mathrm{~kg}$ of soil- $80 \mathrm{mg} \mathrm{N}$ in the form of $\mathrm{CO}\left(\mathrm{NH}_{2}\right)_{2}, 20 \mathrm{mg} \mathrm{P}$ in the form of $\mathrm{KH}_{2} \mathrm{PO}_{4}, 40 \mathrm{mg} \mathrm{K}$ in the form of $\mathrm{KCl}$ and $\mathrm{KH}_{2} \mathrm{PO}_{4}$, and $10 \mathrm{mg} \mathrm{Mg}$ in the form of $\mathrm{MgSO}_{4}$. $7 \mathrm{H}_{2} \mathrm{O}$-and thoroughly mixed. The soil intended for the first and second series of the experiment was placed in pots, whereas the soil intended for the third and fourth series was first polluted with diesel oil at an amount of $7 \mathrm{~cm}^{3} \mathrm{~kg}^{-1}$ soil, mixed, and then placed in the pots. In all experimental series, the soil was moisturized to $60 \%$ of the capillary water capacity. After 7 days since the experiment had been established, 24 seeds of Dactylis glomerata were sown into the soil from Series 2 and 4 . The grass was cut 3 times: on Day 45, Day 75 and Day 105 of the experiment. Soil moisture was monitored throughout the study period, and water losses were compensated with distilled water. Microbiological, biochemical and chemical analyses were carried out immediately after the 3 rd grass cutting, i.e., on the 105th day of the experiment.

\subsection{Methodology of Microbiological Analyses}

A serial dilution method was used to determine counts of organotrophic bacteria (Org), actinobacteria (Act), and fungi (Fun) in all the soil samples according to the procedure presented in work by Borowik et al. [46]. Simultaneously, DNA was extracted from soil samples using the "Genomic Mini AX Soil+" kit, and its presence was confirmed with Real-Time PCR in an Mx3000P thermocycler (Stratagene), using an SYBR Green dye (A\&A Biotechnology, Gdynia, Poland) as a fluorochrome. The PCR mixture contained 1055F (5'-ATGGCTGTCGTCAGCT-3') and 1392R (5'-ACGGGCGGTGTGTAC-3') primers, while the specific primers $341 \mathrm{~F} / 785 \mathrm{R}$ were used to amplify the selected region and prepare the metagenomic data library. The next-generation sequencing was carried out using an Ilumina MiSeq platform (Illumina Inc., San Diego, California, USA), with the paired-end (PE) technology, $2 \times 250 \mathrm{bp}$, using a v2 Illumina kit. The bioinformatic analysis of the hypervariable region V3-V4 of the 16S rRNA gene, after filtering out the chimeric and incomplete sequences, was conducted using the QIIME packages based on reference sequence databases GreenGenes v13_8, by Genomed S.A. Warsaw, Poland.

\subsection{Physical, Chemical and Biological Properties of Soil}

The activity of dehydrogenases was determined according to the procedure provided by Öhlinger [47]; the activities of urease, acid phosphatase, alkaline phosphatase, urease, $\beta$-glucosidase, and arylsulfatase, according to Alef and Nannipieri [48]; and the activity of catalase, according to 
Johnson and Temple [49]. The substrates used in enzymatic activity analyses, activity units, and conditions of analyses were described in our previous work by Borowik et al. [46]. Soil samples were analysed for contents of benzines $\left(\mathrm{C}_{6}-\mathrm{C}_{12}\right)$, mineral oil $\left(\mathrm{C}_{12}-\mathrm{C}_{35}\right)$, aromatic volatile hydrocarbons (BETX), and PAHs -2 rings (naphthalene), 3 rings (anthracene), 4 rings (chrysene, benzo(a)antracene), 5 rings (benzo(a)pyrene, benzo(b)fluoranthene, benzo(k)fluoranthene), and 6 rings (benzo(ghi)perylene, indeno(123-cd)pyrene. The PAH content was determined by Weeseling company (Cracow, Poland) on an Agilent 7890A-5975C gas chromatograph with a mass spectrometer, equipped with an EI/CI ion source, according to the following ISO standards: ISO 18,287 [50], EN ISO 16,703 [51] and EN ISO 22,155 [52]. The procedures used to determine contents of organic carbon, total nitrogen, available phosphorus, available potassium, and available magnesium and to analyze soil $\mathrm{pH}$, exchangeable capacity and soil fraction size distribution were presented in the work by Borowik et al. [46]. The organic carbon content was determined with the Tiurin method according to Nelson and Sommers [53]; total nitrogen content, with the Kjeldahl method according to ISO 11,261 [54]; content of $\mathrm{P}_{\text {available }}$ and $\mathrm{K}_{\mathrm{available}}$, with the method of Egner-Riehm [55]; $\mathrm{Mg}_{\text {available }}$ content, with atomic absorption spectrometry according to Schlichting et al. [56]; granulometric composition, with the aerometric method PN-R-04032 [57] and ISO 11,464 [58]; $\mathrm{pH}_{\mathrm{KCl}}$, with the potentiometric ISO 10,390 [59] method; and exchangeable capacity, with the Kappen method according to Klute [60].

\subsection{Statistical Computations and Analysis}

The determined counts of bacteria and fungi were used to compute the colony development index (CD) and the ecophysiological diversity index (EP), according to De Leij et al. [61]. Relative abundance was visualized using the STAMP 2.1.3. software, based on the two-sided test of statistical hypotheses-G-test (w/Yates') + Fisher's, with the interval confidence method-Asymptotic with CC [62]; the Circos 0.68 package used to present genomic data in the circular system; and the RStudio v1.2.5033 software [63], v3.6.2 system [64], and gplots library [65] were used to generate the heat map. The relative abundance of the bacteria of each taxon was presented from the data for which the contribution was higher than $1 \%$. The indices of diesel oil effect $\left(\mathrm{I}_{\mathrm{DO}}\right)$ and of plant effect $\left(\mathrm{I}_{\mathrm{DR}}\right)$ on the activity of soil enzymes as well as the resistance index (RS) of Dactylis glomerata to diesel oil were computed as well [66]. The contents of benzines $\left(C_{6}-C_{12}\right)$, mineral oil $\left(C_{12}-C_{35}\right)$, aromatic volatile hydrocarbons (BETX) and PAHs determined in the soil directly after its pollution with DO and 105 days after its pollution allowed the computation of the degree of their degradation. Both the counts of soil microorganisms; the activities of soil enzymes; and the values of the CD, EP, $I_{D O}$ and $I_{D R}$ indices were used to calculate homogenous groups with the Tukey test at a significance level of $\mathrm{P}=0.05$, using the Statistica 13.1 package [67]. The results of the analysis of variance (ANOVA) are shown in Table S1.

\section{Results}

\subsection{Counts and Diversity of Microorganisms in the Soil}

Diesel oil significantly stimulated the proliferation of all the microorganisms studied (Figure 1). In the non-sown soil, the number of organotrophic bacteria increased by $180 \%$; that of actinobacteria, by $429 \%$; and that of fungi, by $225 \%$. The cultivation of orchard grass offered convenient conditions, promoting the development of all the analyzed groups of microorganisms. This was confirmed in both the non-polluted soil (increase in population numbers from $16 \%$ in the case of actinobacteria to $47 \%$ in the case of fungi) and the polluted soil (increase in populations numbers of $83 \%$ for actinobacteria and $136 \%$ for fungi). 


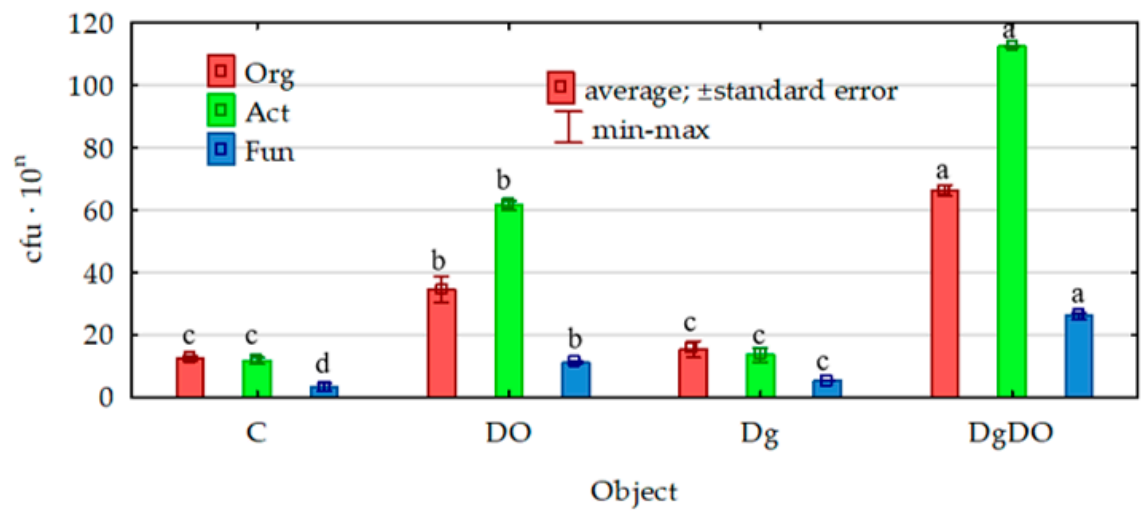

Figure 1. Effect of diesel oil (DO) and Dactylis glomerata (Dg) on the numbers of organotrophic bacteria and actinobacteria, $10^{9} \mathrm{cfu} \mathrm{kg}{ }^{-1} \mathrm{~d} . \mathrm{m}$. soil, and fungi, $10^{7} \mathrm{cfu} \mathrm{kg}{ }^{-1} \mathrm{~d} . \mathrm{m}$. soil. Homogeneous groups denoted with letters $(\mathrm{a}-\mathrm{d})$ were calculated separately for each of the microorganisms. C-non-polluted and non-sown soil, Dg—non-polluted soil sown with Dactylis glomerata, DO-non-sown soil polluted with diesel oil, DgDO—soil polluted with diesel oil and sown with Dactylis glomerata.

Despite the strong promotion of the microorganisms caused by soil pollution with diesel oil, the values of their ecophysiological diversity index (EP) decreased significantly (Figure 2). Theoretically, the EP index can range from 0 to 1 , and the colony development index (CD), from 10 to 100. The greater the value of the EP index, the greater the diversity of microorganisms. For organotrophic bacteria, they decreased from 0.88 to 0.81 in the non-sown soil and from 0.83 to 0.79 in the sown soil; for actinobacteria, from 0.85 to 0.83 and from 0.88 to 0.81 , respectively; and for fungi, from 0.72 to 0.65 and from 0.62 to 0.48 , respectively. Nevertheless, the values of the colony development index (CD) were significantly lower in the non-polluted soil and the DO-polluted soil sown with Dactylis glomerata than in the non-sown soil (Figure 3). This means that slow-growing bacteria (strategy-r) dominated in sown soil, whereas fast-growing bacteria (strategy-K) dominated in non-sown soil.

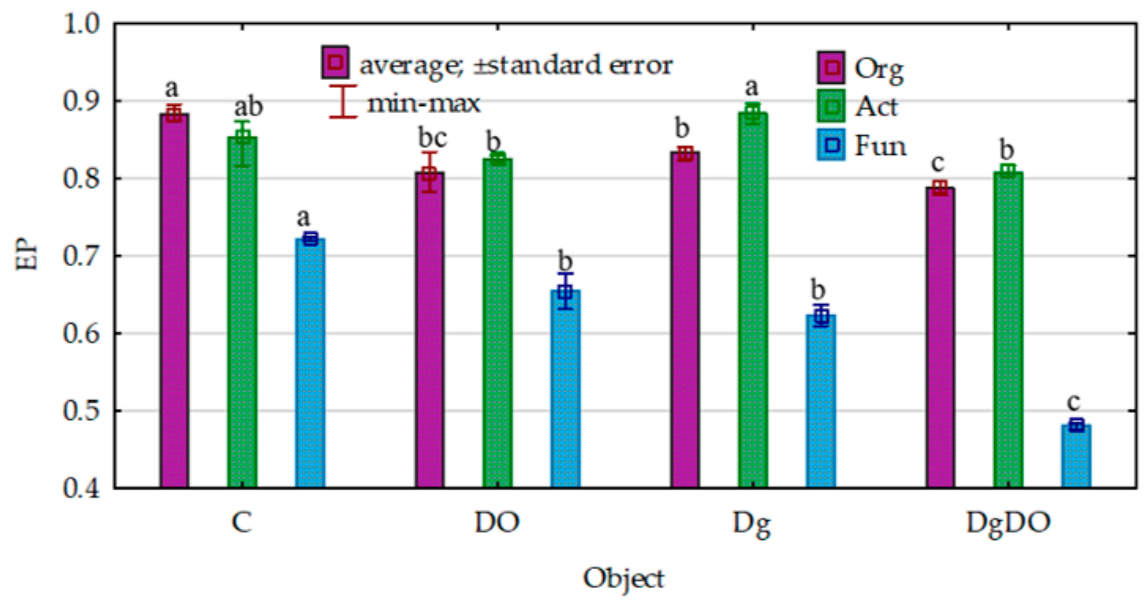

Figure 2. Effect of diesel oil (DO) and Dactylis glomerata (Dg) on the ecophysiological diversity index (EP) of the microorganisms. Homogeneous groups denoted with letters $(a-c)$ were calculated separately for each of the microorganisms. C-non-polluted and non-sown soil, Dg-non-polluted soil sown with Dactylis glomerata, DO—non-sown soil polluted with diesel oil, DgDO—soil polluted with diesel oil and sown with Dactylis glomerata. 


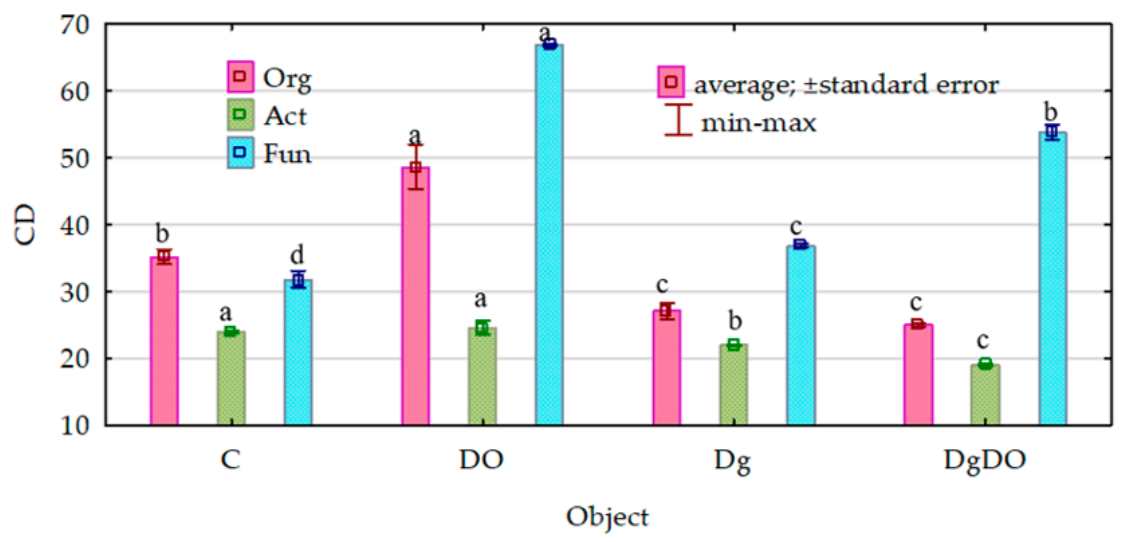

Figure 3. Effect of diesel oil (DO) and Dactylis glomerata (Dg) on the colony development index (CD). Homogeneous groups denoted with letters (a-d) were calculated separately for each of the microorganisms. C-non-polluted and non-sown soil, Dg-non-polluted soil sown with Dactylis glomerata, DO—non-sown soil polluted with diesel oil, DgDO—soil polluted with diesel oil and sown with Dactylis glomerata.

The prevailing taxon at the phylum level was represented by Proteobacteria (Figure 4). In the non-polluted and non-sown soil, they accounted for $28.8 \%$ of total bacteria, and in the soil sown with Dactylis glomerate, for $36.8 \%$ of total bacteria. Soil pollution with DO significantly increased their abundance to $74.3 \%$ in the non-remediated soil and to $67.2 \%$ in the soil remediated with Dactylis glomerata. Such a high abundance of Proteobacteria caused lower operational taxonomic unit (OTU) numbers of most of the other phyla. It was especially noticeable for Actinobacteria, Acidobacteria, Chloroflexi, Gemmatimonadetes and Firmicutes, whose OTU numbers in the DO-polluted non-sown soil were lower by $11.4 \%, 8.7 \%, 6.3 \%, 5.5 \%$ and $5.2 \%$, respectively, compared to in the non-polluted and non-sown soil. Slightly lesser changes were observed in the soil remediated with Dactylis glomerata.

Changes observed already at the phylum level in the bacterial structure were also reflected in the other taxa (Figure 5a,b). Regardless of the soil cultivation variant, among the phylum Proteobacteria, bacteria of the class Alphaproteobacteria predominated in the non-polluted soil $(17.42 \%)$, and Gammaproteobacteria, in the DO-polluted soil (33.76\%). Orchard grass cultivation contributed to higher OTU numbers of three (Betaproteobacteria, Deltaproteobacteria, Gammaproteobacteria) out of the four identified classes. In turn, diesel oil increased the abundance of Gammaproteobacteria by as much as 25 times in the non-sown soil, and 3.9 times in the soil sown with Dactylis glomerata. This spectacular increase in the OTU number of the Gammaproteobacteria class in the non-sown soil was caused mainly by the bacteria from orders Pseudomonadales and Xanthomonadales, and in the sown soil, by the Alteromonadales, PYR10d3 and Xanthomonadales bacteria. Interesting dependencies were also observed for less abundant taxa. The cultivation of Dactylis glomerata in the DO-polluted soil increased the population numbers of bacteria from the following classes-Acidobacteria- 6 (o_iii1-15), Holophagae (o_Holophagales), Acidimicrobiia (o_Acidimicrobiales), Saprospirae (o_Saprospirales), Clostridia (o_Clostridiales), TM7-3 (o_I025) and Pedosphaerae (o_Pedosphaerales)—and decreased the numbers of Acidobacteriia (o_Acidobacteriales), Solibacteres (o_Solibacterales), Actinobacteria (o_Actinomycetales), Thermoleophilia (o_Solirubrobacterales), Sphingobacteriia (o_Sphingobacteriales), Ktedonobacteria (o_JG30-KF-AS9), Bacilli (o_Bacillales), Gemmatimonadetes (o_Ellin5290) and Spartobacteria (o_Chthoniobacterales). Despite the diversified responses of the mentioned taxa to soil pollution with diesel oil and to the cultivation of Dactylis glomerata, we have managed to identify the so-called core bacteriobiome, typical of the soils from all the variants studied. It was constituted by bacteria belonging to Actinomycetales (c_Actinobacteria); Burkholderiales (c_Betaproteobacteria); Caulobacterales, Rhizobiales, Rhodospirillales, and Sphingomonadales (c_Alphaproteobacteria); and Xanthomonadales (c_Gammaproteobacteria). 

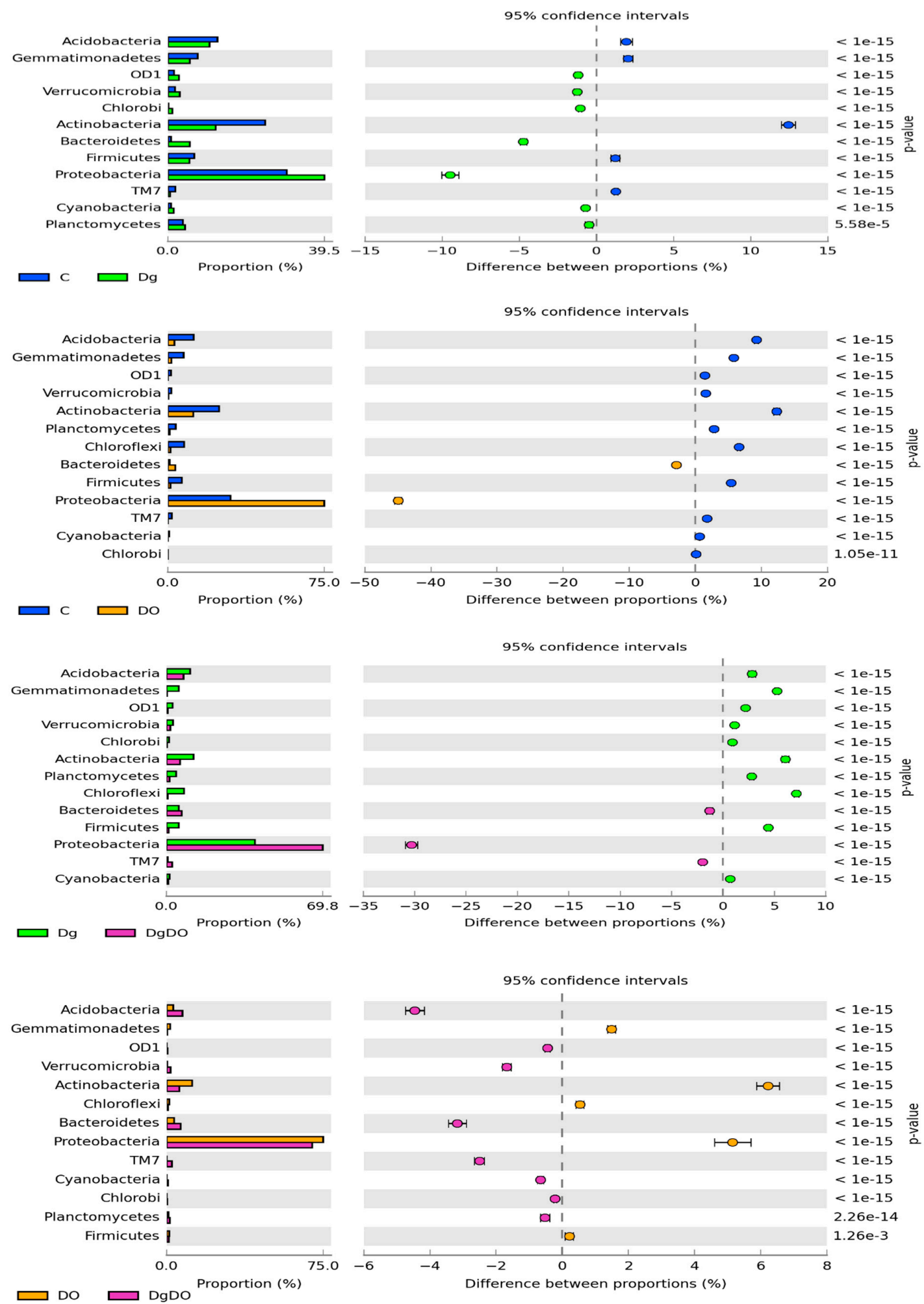

Figure 4. The relative abundance of the dominant bacterial type in the soil with a difference between proportions $\geq 1 \%$. C-non-polluted and non-sown soil, Dg-non-polluted soil sown with Dactylis glomerata, DO—non-sown soil polluted with diesel oil, DgDO—soil polluted with diesel oil and sown with Dactylis glomerata. 


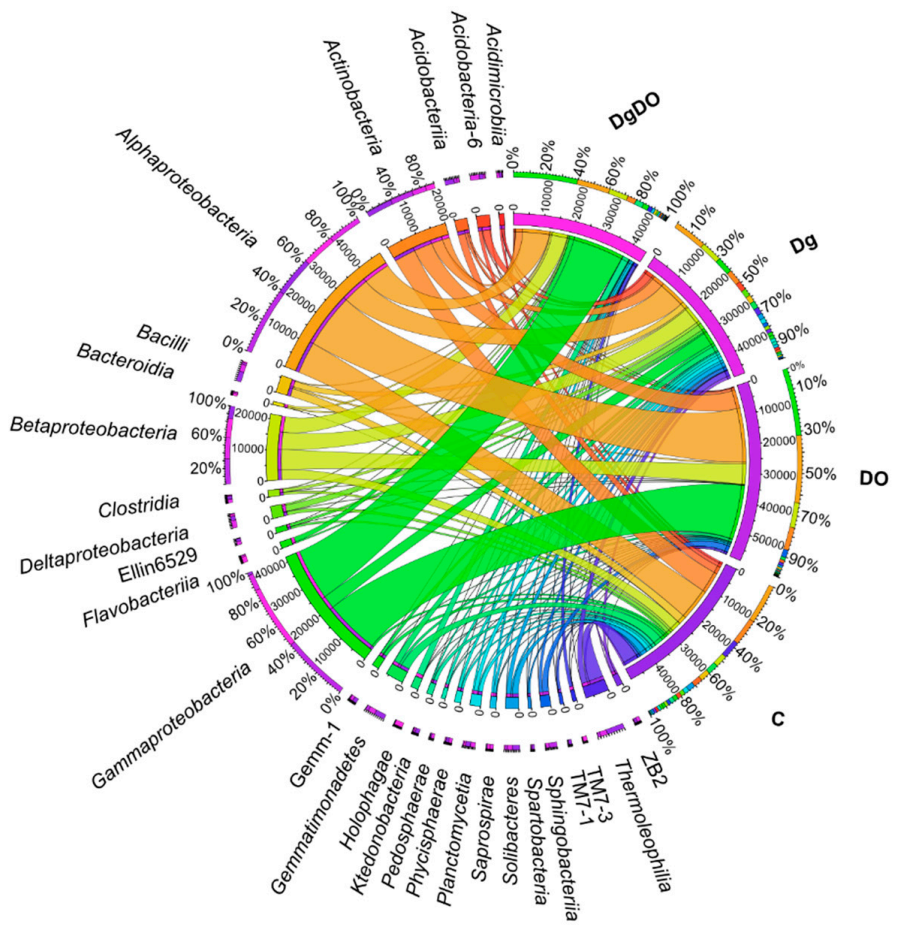

(a)

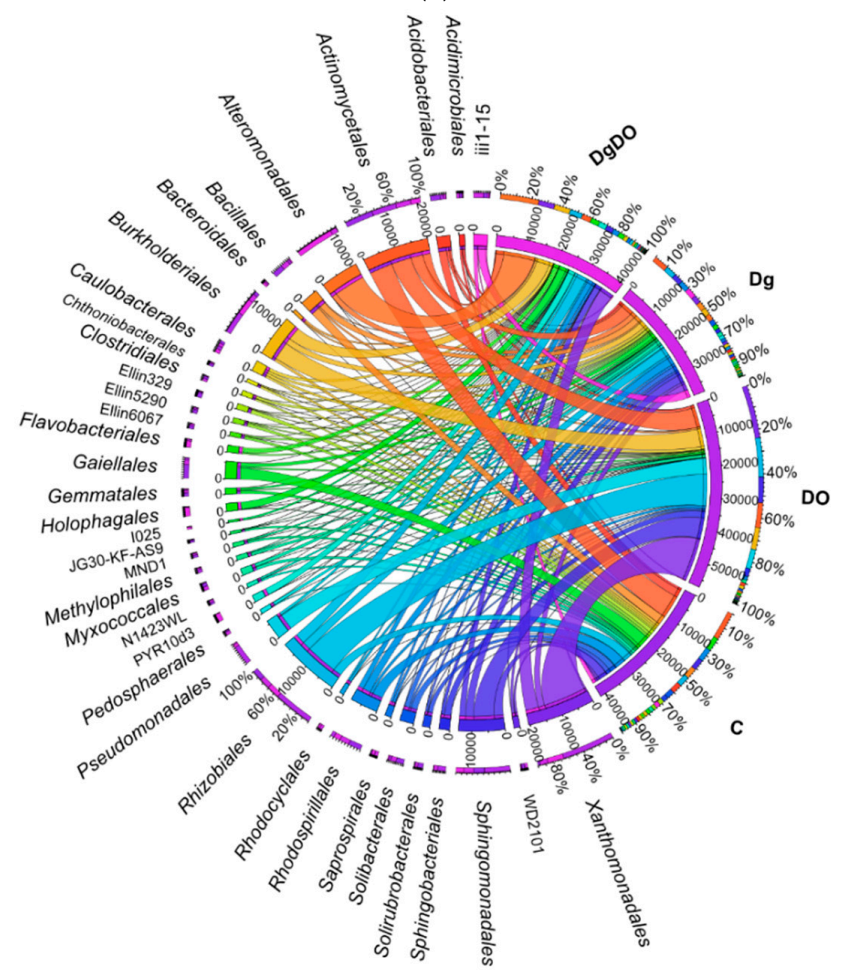

(b)

Figure 5. The relative abundance of the dominance class (a) and order (b) of bacteria in soil with a difference between proportions $\geq 1 \%$. C-non-polluted and non-sown soil, $\mathrm{Dg}$-non-polluted soil sown with Dactylis glomerata, DO—non-sown soil polluted with diesel oil, DgDO—soil polluted with diesel oil and sown with Dactylis glomerata.

Diesel oil and orchard grass also modified bacterial diversity at the family level (Figure 6). In the non-sown soil, the highest OTU numbers were noted for the bacteria from the Gaiellaceae (2644), 
Sphingomonadaceae (2577) and Rhodospirillaceae (2298) families. After soil pollution with DO, the prevailing families included Xanthomonadaceae (13,560 OTU), Hyphomicrobiaceae (9343 OTU), Sphingomonadaceae (6589 OTU), Oxalobacteraceae (4159 OTU) and Nocardiaceae (4184 OTU), and after sowing Dactylis glomerata into the soil not polluted with DO, the prevailing family turned out to be Sphingomonadaceae (2243 OTU). In turn, orchard grass cultivation on the DO-polluted soil promoted the development of bacteria from the Alteromonadaceae (9931 OTU), Xanthomonadaceae (4101 OTU) and Comamonadaceae (3538 OTU) families. Therefore, the high OTU numbers noted for the families identified in the DO-polluted non-sown soil were mainly affected by the Rhodanobacter, Parvibaculum, Sphingomonas and Rhodococcus genera. Considering the OTU numbers higher than $1 \%$ ascribed to individual bacterial genera, worthy of notice is that more genera were classified in the DO-polluted than in the non-polluted soil (Figure 7). The core bacteria were identified for each soil variant. In total, 24 various genera were identified of which only two, Parvibaculum and Rhodococcus, were characteristic for the DO-polluted soils, and another two, Kaistobacter and Rhodoplanes, for the non-polluted soils, and finally, HB2-32-21 was characteristic for the soils sown with Dactylis glomerata. The bacteria representing Bacillus, Candidatus Koribacter, DA101, Nocardioides, Pseudonocardia and Streptomyces occurred as the bio-core only in the non-polluted non-sown soil; Candidatus Solibacter, in the non-polluted soil sown with Dactylis glomerata; Alkanindiges, Burkholderia, Pseudomonas, Rhodanobacter and Sphingomonas, in the non-sown but DO-polluted soil; and finally, Flavobacterium, Geothrix, Gordonia, Lysobacter, Methylibium, Mycobacterium, and Phenylobacterium, in the DO-polluted soil sown with Dactylis glomerata.

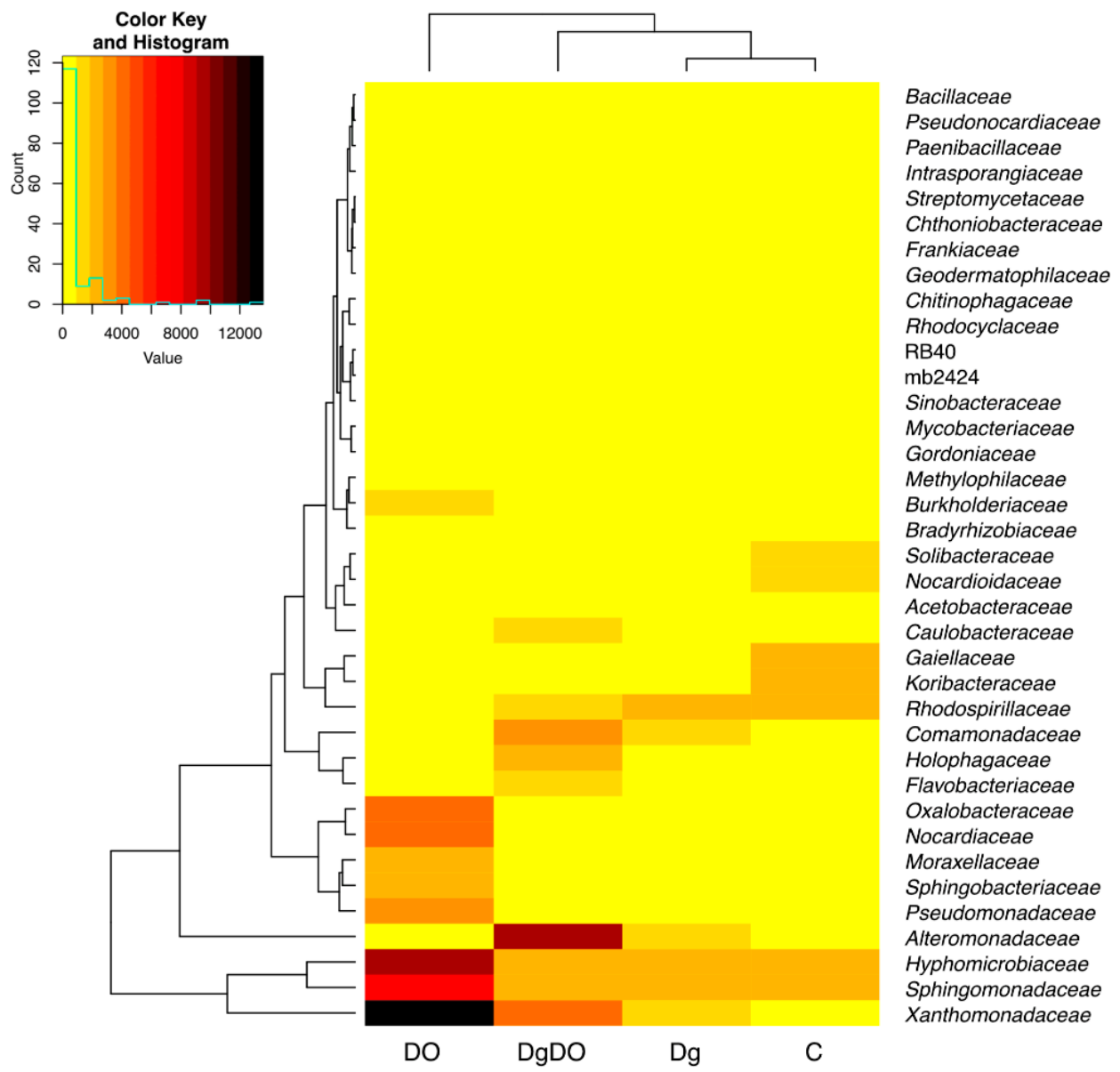

Figure 6. Heat map and relationships of the operational taxonomic unit (OTU) numbers of 37 bacterial families in the soil with a difference between proportions $\geq 1 \%$. C-non-polluted and non-sown soil, Dg—non-polluted soil sown with Dactylis glomerata, DO-non-sown soil polluted with diesel oil, DgDO—soil polluted with diesel oil and sown with Dactylis glomerata. 


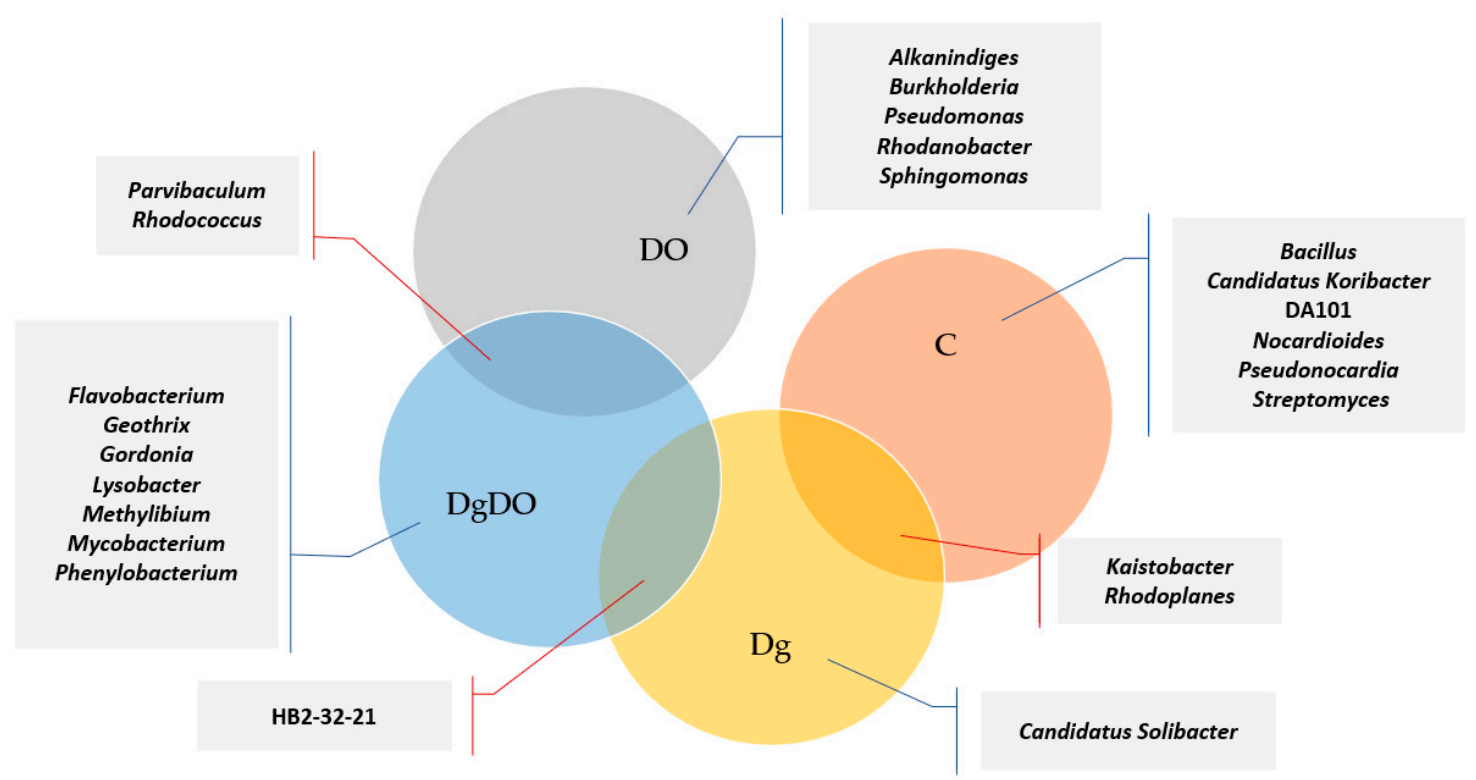

Figure 7. Venn diagram showing unique and common genera of bacteria, based on OTU > 1\%.

\subsection{Activity of Soil Enzymes}

Diesel oil enhanced the activities of all soil enzymes, whereas orchard grass only enhanced the activity of dehydrogenases, catalase and arylsulfatase (Table 1). Dehydrogenase, catalase, $\beta$-glucosidase and arylsulfatase activity were positively correlated with the number of microorganisms (Table S2). A positive correlation was also found between dehydrogenase, urease, $\beta$-glucosidase, alkaline phosphatase and the Shannon index at the genus level.

Table 1. Effect of diesel oil (DO) and Dactylis glomerata (Dg) on soil enzyme activity, kg d.m. soil h $\mathrm{h}^{-1}$.

\begin{tabular}{cccccccc}
\hline \multirow{2}{*}{ Object $^{1}$} & Deh & Cat & Ure & Glu & Pac & Pal & Aryl \\
\cline { 2 - 7 } & $\begin{array}{c}\mu \text { mol } \\
\text { TFF }\end{array}$ & Mol O & $\begin{array}{c}\text { mmol } \\
\text { N-NH }\end{array}$ & & & mmol PNP & \\
\hline C & $0.666^{\mathrm{c}}$ & $0.098^{\mathrm{d}}$ & $0.364^{\mathrm{b}}$ & $0.277^{\mathrm{c}}$ & $1.201^{\mathrm{b}}$ & $0.160^{\mathrm{b}}$ & $0.102^{\mathrm{d}}$ \\
DO & $3.137^{\mathrm{b}}$ & $0.290^{\mathrm{c}}$ & $2.134^{\mathrm{a}}$ & $0.334^{\mathrm{a}}$ & $1.298^{\mathrm{a}}$ & $0.346^{\mathrm{a}}$ & $0.270^{\mathrm{b}}$ \\
Dg & $2.920^{\mathrm{b}}$ & $0.727^{\mathrm{b}}$ & $0.235^{\mathrm{c}}$ & $0.265^{\mathrm{c}}$ & $0.930^{\mathrm{d}}$ & $0.122^{\mathrm{c}}$ & $0.244^{\mathrm{c}}$ \\
DgDO & $5.987^{\mathrm{a}}$ & $1.286^{\mathrm{a}}$ & $0.387^{\mathrm{b}}$ & $0.316^{\mathrm{b}}$ & $1.034^{\mathrm{c}}$ & $0.154^{\mathrm{b}}$ & $0.659^{\mathrm{a}}$ \\
\hline
\end{tabular}

${ }^{1} \mathrm{C}$-non-polluted and non-sown soil, Dg-non-polluted soil sown with Dactylis glomerata, DO—non-sown soil polluted with diesel oil, DgDO—soil polluted with diesel oil and sown with Dactylis glomerata. Homogeneous groups denoted with letters (a-d) were calculated separately for each enzyme. Deh—dehydrogenases, Cat—catalase, Ure-urease, Glu- $\beta$-glucosidase, Pac—acid phosphatase, Pal—alkaline phosphatase, Aryl-arylsulfatase, TFF-triphenyl fomazan, PNP-p-nitrophenol.

The modification of the biochemical properties of soil due to its pollution with DO and its remediation with Dactylis glomerata was reflected in the indices of the effect of diesel oil $\left(\mathrm{IF}_{\mathrm{DO}}\right)$ and indices of the effect of orchard grass $\left(\mathrm{IF}_{\mathrm{Dg}}\right)$ on the activities of individual enzymes (Figures 8 and 9). The effect of diesel oil on the activities of dehydrogenases, catalase, urease, $\beta$-glucosidase and alkaline phosphatase was significantly stronger in the non-remediated soil, whereas its effect on the activities of acidic phosphatase and arylsulfatase was stronger in the soil remediated with Dactylis glomerata. Considering the $\mathrm{IF}_{\mathrm{DO}}$ values noted for the non-remediated soil, the enzymes are ordered as follows (starting from the highest value of the index)-Ure (4.863) > Deh (3.710) > Cat (1.959) > Aryl (1.647) > Pal (1.163) > Glu (0.206) > Pac (0.081) — whereas in the soil remediated with Dactylis glomerata, they are ordered as follows: Aryl (1.701) > Deh (1.050) > Cat (0.769) > Ure (0.647) > Pal (0.262) > Glu (0.192) $>$ Pac (0.112). The values of the index $\left(\mathrm{IF}_{\mathrm{Dg}}\right)$ of the effect of soil remediation with Dactylis glomerata 
were highly varied. Both in the non-polluted and DO-polluted soils, the $\mathrm{IF}_{\mathrm{Dg}}$ values determined for dehydrogenases, catalase and arylsulfatase were positive, whereas these determined for urease, $\beta$-glucosidase, acidic phosphatase and alkaline phosphatase were negative.

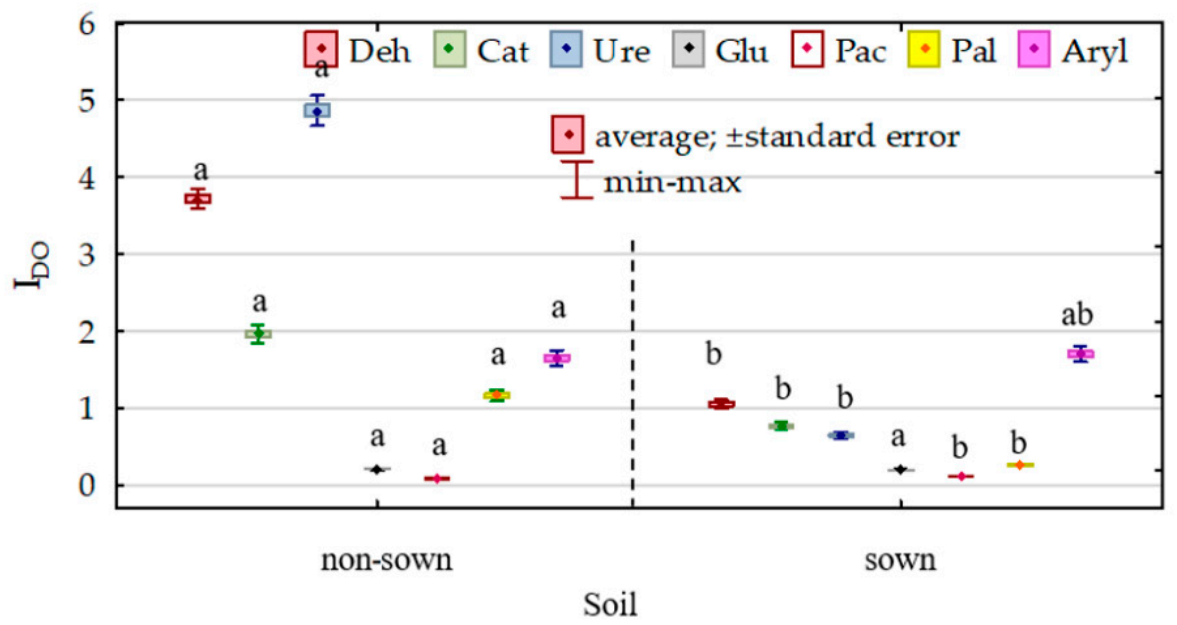

Figure 8. Index of the effect of diesel ( $\left.\mathrm{I}_{\mathrm{DO}}\right)$ on soil enzyme activity. Homogeneous groups denoted with letters $(a, b)$ were calculated separately for each enzyme.

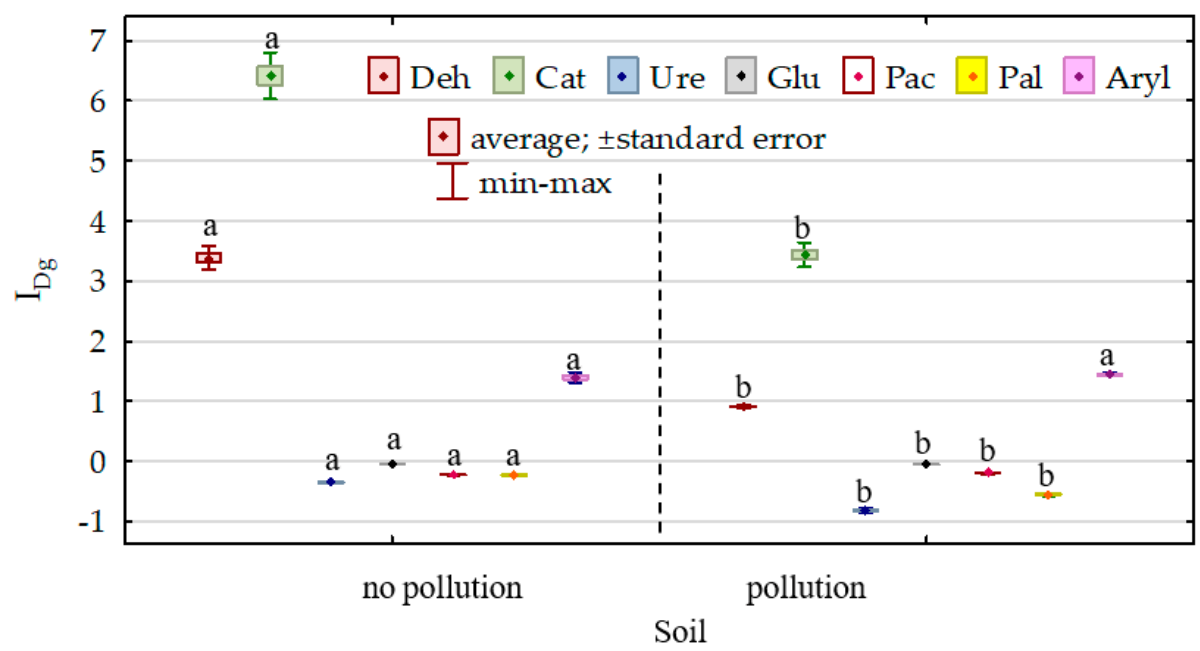

Figure 9. Index of the effect of Dactylis glomerata $\left(\mathrm{I}_{\mathrm{Dg}}\right)$ on soil enzyme activity. Homogeneous groups denoted with letters $(a, b)$ were calculated separately for each enzyme.

\subsection{Degradation of Hydrocarbons}

Chemical compounds that are constituents of diesel oil were degraded in the soil at various rates, depending on the soil cultivation variant (Table 2). In the non-sown soil, hydrocarbons degraded more slowly than in the soil sown with Dactylis glomerata. After sowing the soil with Dactylis glomerata grass, the degradation of the compounds contained in diesel oil was $13 \%$ higher than in non-sown soils. On average, over $90 \%$ degradation was noted for xylenes, ethylbenzene, toluene and naphthalene; $87-57 \%$ degradation was noted for anthracene, benzines $\left(C_{6}-C_{12}\right)$, benzene and mineral oils $\left(C_{12}-C_{35}\right) ; 36-26 \%$ degradation was noted for benzo(a)pyrene, chrysene, benzo(k)fluoranthene, benzo(a)anthracene and benzo(b)fluoranthene; and $11 \%$ degradation was noted for indeno(123-cd)pyrene. 
Table 2. Degradation of hydrocarbons in soil, non-sown and sown, contaminated with diesel oil (DO), \%.

\begin{tabular}{|c|c|c|c|c|c|c|c|}
\hline Object & $\mathrm{C}_{6}-\mathrm{C}_{12}$ & $C_{12}-C_{35}$ & Ben & EtB & Tol & Xyl & Nap \\
\hline NS & $65.92^{b}$ & $52.26^{\mathrm{b}}$ & $44.50^{b}$ & $98.01^{a}$ & $97.86^{b}$ & $98.61^{a}$ & $97.22^{b}$ \\
\hline $\mathrm{S}$ & $82.79^{a}$ & $60.87^{\mathrm{a}}$ & $75.00^{\mathrm{a}}$ & $99.36^{\mathrm{a}}$ & $99.31^{\mathrm{a}}$ & $99.55^{\mathrm{a}}$ & $98.86^{a}$ \\
\hline Object & Ant & Chr & $\mathrm{BaA}$ & $\mathrm{BaP}$ & $\mathrm{BbF}$ & BkF & IP \\
\hline NS & $80.52^{b}$ & $13.91^{\mathrm{b}}$ & $18.75^{b}$ & $27.78^{b}$ & $18.18^{b}$ & $22.00^{b}$ & $10.00^{b}$ \\
\hline $\mathrm{S}$ & $92.78^{a}$ & $52.17^{\mathrm{a}}$ & $37.50^{\mathrm{a}}$ & $44.44^{\mathrm{a}}$ & $33.33^{a}$ & $40.00^{\mathrm{a}}$ & $12.50^{\mathrm{a}}$ \\
\hline
\end{tabular}

\subsection{Response of Dactylis Glomerata to Diesel Oil}

Diesel oil added to the soil significantly impaired the growth and development of Dactylis glomerata (Figure 10). It had an especially adverse effect at the initial stage of orchard grass growth, as shown by a very low value of the index of its resistance $(\mathrm{RS}=0.02)$ to soil pollution. With time, Dactylis glomerata was observed to better adapt to the adverse conditions. The index of its resistance (RS) to soil pollution with DO increased successively from 0.02 (cut I) to 0.39 (regrowth III).

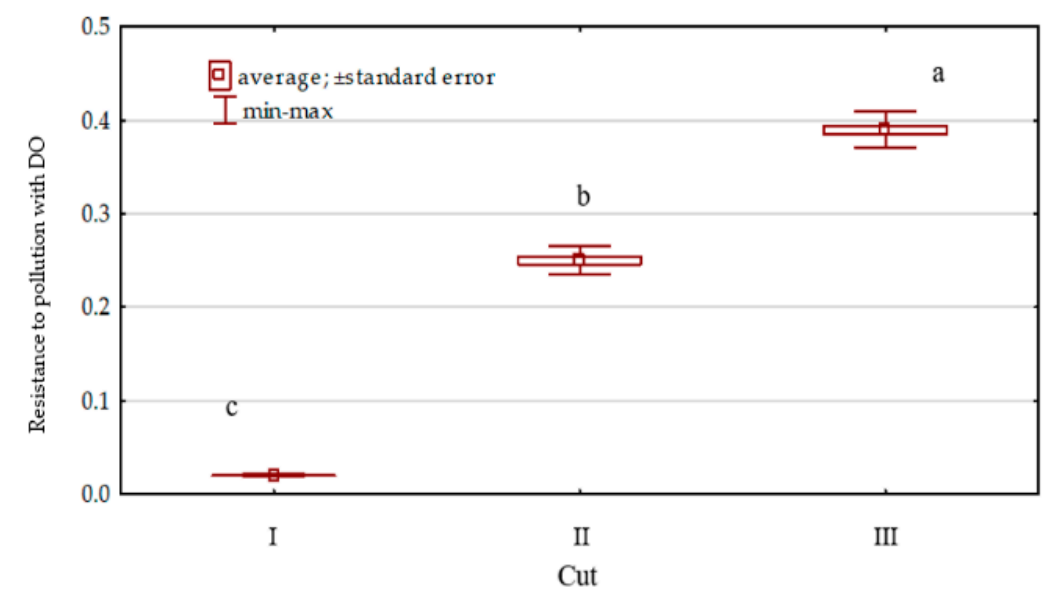

Figure 10. Dactylis glomerata resistance to soil pollution with diesel oil (DO) soil contamination.

\section{Discussion}

\subsection{Counts and Diversity of Microorganisms in the Soil}

Soil pollution with diesel oil as well as the sowing of non-polluted and polluted soils with Dactylis glomerata had a significant impact on the diversity and composition of the soil microbiome. The results of our experiment are consistent with findings reported by Yang et al. [2], Estendorfer et al. [39], Gu et al. [68], Kumar et al. [69], Gałazka et al. [70], Delgado-Baquerizo et al. [71] and Wemheuer et al. [72]. Microorganisms colonizing the soil environment are responsible for most of the geochemical processes, including nutrient metabolism and energy transfer, whereas the adhesion of microbial cells in the soil, their growth and their development are determined by the granulometric composition of soil; availability of nutrients; and contents of carbon, water, pollutants and substances secreted by plants $[6,7,29]$. The statistical analysis of the data obtained in our study demonstrated that soil pollution with diesel oil significantly stimulated the abundance of all microorganisms tested, whereas the cultivation of Dactylis glomerata enhanced their proliferation. This strong effect of 
diesel oil on the promotion of microorganisms was reflected in significantly decreased values of the ecophysiological diversity index (EP) of both bacteria, actinobacteria, and fungi.

The metagenomic data obtained demonstrated Proteobacteria taxa to be the most abundant in all the soil samples. Hence, our results did not diverge from most of the literature data $[2,39,68,70,71]$. Soil pollution with diesel oil reduced the abundance of Actinobacteria, Acidobacteria, Chloroflexi, Gemmatimonadetes and Firmicutes. Next to Proteobacteria, Acidobacteria, Actnobacteria, and Planctomycetes, Delgado-Baquerizo et al. [71] successively identified Verrucomicrobia Bacteroidetes, Gemmatimonadetes, Firmicutes, Armatimonadetes, TM7 and WS2. They claimed the repeatability of bacterial phylotypes in the soils of the world to be low. Changes in the diversity of microorganisms in the soil polluted with petroleum-based products were also confirmed by Kumar et al. [69]. In the present study, the samples of DO-polluted soil were also dominated by Proteobacteria, followed by Bacteroidetes and Actinobacteria. In turn, apart from Proteobacteria, Yang et al. [2] also demonstrated the presence of Actinobacteria and Firmicutes as well as Bacteroidetes and Chloroflexi. In our study, Chloroflexi and Gemmatimonadetes were also identified in the soil apart from the bacteria mentioned above. This was probably due to the trophic changes in the soil exposed to the pressure of diesel oil. For this reason, Chloroflexi-being facultative anaerobes-could faster adapt to the adverse conditions [68,73]. Bacteria present in the soils polluted with petroleum-based products aid the survivability of aerobic heterotrophs [73].

A surprising finding was Gemmatimonadetes' response to soil contamination with diesel oil. According to DeBruyn [74], they represent approximately $2 \%$ of the soil bacterial population. In the non-polluted soil analyzed in our study, they accounted for $3-5 \%$, whereas after soil pollution with DO, their contribution in the soil microbiome decreased to barely $0.16-1.4 \%$. These results are in opposition to the findings reported by Gałazka et al. [70], who proved the positive response of Gemmatimonadales to petroleum-based products.

Changes in the bacterial structure in soils polluted with diesel oil are determined not only by seasonal variations in the availability of nutrients and $\mathrm{C}$ and $\mathrm{N}$ resources but also by interactions between the root system of plants and bacteria [39], the moisture and oxygen contents in the soil [75], and the species of the grown plant [72]. Modifications of the structure of microbial communities, observed in our study, were also demonstrated in the experiment conducted by Estendorfer et al. [39], where the soil sown with Dactylis glomerata was dominated by Sinobacteriaceae, Hyphomicrobiaceae, Comamonadaceae, Chitinophagaceae and Xanthomonadaceae, whereas the non-sown soil was dominated by Chitinophagaceae, Hyphomicrobiaceae and Sinobacteriaceae.

In the present study, among the prevailing phyla worthy of notice are the genera of Alkanindiges, Rhodococcus, Burkholderia, Candidatus Koribacter, Candidatus Solibacter, Geothrix, Lysobacter, Methylibium, Mycobacterium, Parvibaculum, Pseudomonas, Phenylobacterium, Rhodanobacter, Rhodococcus, Sphingomonas, HB2-32-21, Kaistobacter and Burkholderia but also bacteria from the Bacillus and Flavobacterium genera. According to Yang et al. [2], Raju et al. [76], Mukherjee et al. [77] and Røberg et al. [78], they are able to degrade petroleum-based products. However, as reported by Islam et al. [73] and Hemkemeyer et al. [79], the bacterial diversity in the soil environment is determined by the abundance of energy and nutrient resources, whereas the availability of these resources may be diminished for certain bacteria by the adverse effects of diesel oil on the physical properties of soil.

\subsection{Activity of Soil Enzymes}

The basic source of soil enzymes is microorganisms and, to a lesser extent, plants and other organisms. The enzyme activity is positively correlated with the abundance and structure of microorganisms $[12,14,21,80]$. Therefore, apart from microorganisms, soil enzymes are sensitive biomarkers of the soil environment [21,80-83]. In the presented research, DO soil contamination both changed the structure of bacteria and increased their numbers. These elements determined DO's increasing of the activities of dehydrogenases, catalase, urease, acid phosphatase, alkaline phosphatase, $\beta$-glucosidase and arylsulfatase. The response of enzymes from the classes of oxidoreductases and hydrolases to DO hydrocarbons was similar. The same sensitivity of enzymes from these 
classes to the varying conditions of the soil environment was indicated by Borowik et al. [22] and Wyszkowska et al. [84]. According to Xiaoyan et al. [85], enzymatic activity is dependent on readily available carbon sources.

The increased activities of soil enzymes in the soil exposed to DO pollution, observed in the present study, are due to the stimulated proliferation of soil microorganisms by this petroleum-based product. Many studies $[4,73,86]$ have proved a positive correlation between the abundance of microorganisms in the soil and enzymatic activity. In the present study, DO served as an energy substrate to the microorganisms, hence we could observe its positive effect on the microbial community and, resultantly, on the enhanced activities of soil enzymes, the majority of which are of microbiological origin $[85,87]$. The positive correlation between the number of microorganisms and the enzymatic activity of soil is also affected by plants, which indirectly affect the synthesis of enzymes by stimulating microorganisms to grow through root secretions [88,89]. In turn, Burns et al. [90] claimed that the preservation of high enzymatic activity in the polluted soil might be due to the sorption of exoenzymes on mineral and organic colloids.

\subsection{Degradation of Hydrocarbons}

Soils polluted with petroleum-based products have increased concentrations of PHAs [91,92]. When they are not severely polluted, the microorganisms colonizing them can lead to their self-treatment [34,93,94]. According to An et al. [95], bacteria representing Proteobacteria, Firmicutes, Actinobacteria, Chloroflexi and Bacteroidetes are involved in the degradation of hydrocarbons. This process intensifies when aided by plant root secretions, which activate microorganisms of the rhizosphere $[92,96,97]$. Plants also secrete enzymes into the rhizosphere that degrade soil hydrocarbons. They can also take up hydrocarbons contained in petroleum products [98] and degrade them in their tissues [91]. This system of decomposition of toxic organic compounds is compared to the mammalian liver and is called the "green liver model" [91,99]. According to this model, petroleum compounds undergo transformation in three stages: enzymatic modification, conjugation with low-molecular plant organic compounds and sequestration in a vacuole or cell wall. In the present study, the degradation of DO hydrocarbons was significantly faster in the soil sown with Dactylis glomerata than in the non-sown soil. Plants useful in PAH removal from soil also include Mariscus alternifolius and Fimbristylis ferruginea [86]; Festuca arundinacea, F. elata and F. gigantea [80]; and Hylotelephium spectabile [87]. A significant role of plants in the phytoremediation of petroleum-based pollutants was also confirmed by Jing et al. [100] and Iqbal et al. [37]. The transformation of hydrocarbons was also dependent on their structure and properties, i.e., faster degradation was observed for those with a simpler structure than for the more complex ones. The same conclusion was drawn by Wyszkowska et al. [29] and Fatima et al. [36]. The choice of an appropriate plant represents an effective strategy for the remediation of soil polluted with crude oil [36]. Investigations of this type are extremely important, because the same bioremediation methods employed in various types of soil lead to unpredictable and inconsistent effects during the removal of petroleum-based pollutants [101].

The present research focuses on biological tests, such as soil enzymes and various taxa of microorganisms. They were used as indicators for assessing soil contaminated with diesel oil. It has been shown that both microorganisms and soil enzymes react very quickly to changes in the soil. Microorganisms and, above all, enzymes can be used in the biomonitoring of contaminated soils.

\section{Conclusions}

Soil pollution with DO and soil sowing with Dactylis glomerata increased population numbers of bacteria and fungi as well as the abundance of the phylum Proteobacteria. At the same time, they reduced the relative abundance of Actinobacteria, Acidobacteria, Chloroflexi, Gemmatimonadetes and Firmicutes, and decreased the values of the ecophysiological diversity index (EP) of the microorganisms tested. In the non-polluted soils, the core microbiome was represented by Kaistobacter and Rhodoplanes, whereas in DO-polluted soils it was represented by Parvibaculum and Rhodococcus. Diesel oil 
stimulated the proliferation of microorganisms and activities of all soil enzymes tested, while Dactylis glomerata stimulated the activities of only three enzymes, i.e., dehydrogenases, catalase and arylsulfatase. Additionally, Dactylis glomerata proved to be a plant slightly resistant to DO hydrocarbons. With vegetation time proceeding, its resistance increased, which was due to the degradation of individual hydrocarbons. This degradation process was dependent on the chemical structure and chemical properties of the hydrocarbons, and was the faster in the case of the simplest compounds, i.e., xylenes, ethylbenzene, toluene, naphthalene and anthracene, and the slowest in the case of benzo(a)anthracene, benzo(b)fluoranthene and indeno(123-cd)pyrene. Despite the high sensitivity of Dactylis glomerata to soil pollution with DO, its usability for the removal of DO hydrocarbons was significant, mainly due to its effect on the soil microbiome and activities of enzymes representing oxidoreductases. Dactylis glomerata increased the degradation of gasoline fractions $\left(C_{6}-C_{12}\right)$ by $17 \%$; mineral oil $\left(C_{12}-C_{35}\right)$, by $9 \%$; benzene by $31 \%$; anthracene, by $12 \%$; chrysene, by $38 \%$; benzo[a]anthracene, by $19 \%$; benzo(a)pyrene, by $17 \%$; benzo[b]fluoranthene, by $15 \%$; and benzo(k)fluoranthene, by $18 \%$. It has been shown that tests of microbiological, biochemical and chemical properties can be used in the evaluation of the effects of soil contamination with diesel oil. The methods used are fast and sensitive in the diagnosis of soil contamination with petroleum products, and a combination of all these tests gives a reliable assessment of the state of soils.

Supplementary Materials: The following are available online at http://www.mdpi.com/1424-8220/20/12/3362/s1, Table S1: Significance tests carried out using the analysis of variance (ANOVA), Table S2: Covariance matrices for intergroup effects.

Author Contributions: A.B. and J.W. conceived and designed the ideas and wrote the manuscript with the help of J.K.; A.B. conducted the experiments, collected and analyzed the data, and wrote the manuscript with the help of J.W. and J.K.; A.B. and M.K. did bioinformatic analysis and visualization of the data; and all authors contributed to the final version of this manuscript. All authors have read and agreed to the published version of the manuscript.

Funding: The project was financed by the University of Warmia and Mazury in Olsztyn (Poland) as part of the topic No. 20.610.014-110 and financially supported by the Minister of Science of Higher Education in the range of the program entitled "Regional Initiative of Excellence" for the years 2019-2022; Project No. 010/RID/2018/19; amount of funding 12.000.000 PLN.

Conflicts of Interest: The authors declare no conflict of interest.

\section{References}

1. Yang, Y.; Xu, M.; He, Z; Guo, J.; Sun, G.; Zhou, J. Microbial electricity generation enhances decarbomodiphenyl ether (BDE-209) degradation. PLoS ONE 2013, 8, e70686. [CrossRef]

2. Yang, S.; Wen, X.; Zhao, L.; Shi, Y.; Jin, H. Crude oil treatment leads to shift of bacterial communities in soils from the deep active layer and upper permafrost along the China-Russia crude oil pipeline route. PLoS ONE 2014, 9, e96552. [CrossRef] [PubMed]

3. Ehsani, E.; Dumolin, C.; Arends, J.B.A.; Kerckhof, F.M.; Hu, X.; Vandamme, P.; Boon, N. Enriched hydrogen-oxidizing microbiomes show a high diversity of co-existing hydrogen-oxidizing bacteria. Appl. Microbiol. 2019, 103, 8241-8253. [CrossRef] [PubMed]

4. Akwukwaegbu, R.N.; Okerentugba, P.O.; Okpokwasili, G.C.; Stanley, H.O.; Ugboma, C.J. Hydrocarbon degradation potential of heterotrophic bacteria isolated from oil polluted sites in Sakpenwa community in rivers state. SAJRM 2019, 4, 1-12. [CrossRef]

5. Smułek, W.; Sydow, M.; Zabielska-Matejuk, J.; Kaczorek, E. Bacteria involved in biodegradation of creosote PAH - A case study of long-term contaminated industrial area. Ecotoxicol. Environ. 2020, 187, 109843. [CrossRef] [PubMed]

6. Purkamo, L.; Kietäväinen, R.; Nuppunen-Puputti, M.; Bomberg, M.; Cousins, C. Ultradeep microbial communities at $4.4 \mathrm{~km}$ within crystalline bedrock: Implications for habitability in a planetary context. Life 2020, 10, 2. [CrossRef]

7. Ite, A.E.; Ibok, U.J. Role of plants and microbes in bioremediation of petroleum hydrocarbons contaminated soils. IJEBB 2019, 7, 1-19. 
8. Jiao, S.; Chen, W.; Wang, E.; Wang, J.; Liu, Z.; Li, Y.; Wei, G. Microbial succession in response to pollutants in batch-enrichment culture. Sci. Rep. 2016, 6, 21791. [CrossRef]

9. Kucharski, J.; Tomkiel, M.; Boros, E.; Wyszkowska, J. The effect of soil contamination with diesel oil and petrol on the nitrification process. J. Elem. 2010, 15, 111-118. [CrossRef]

10. Abena, M.T.B.; Chen, G.; Chen, Z.; Zheng, X.; Li, S.; Li, T.; Zhong, W. Microbial diversity changes and enrichment of potential petroleum hydrocarbon degraders in crude oil-, diesel-, and gasoline-contaminated soil. 3 Biotech. 2020, 10, 42. [CrossRef]

11. Lipińska, A.; Kucharski, J.; Wyszkowska, J. The effect of polycyclic aromatic hydrocarbons on the structure of organotrophic bacteria and dehydrogenase activity in soil. Polycycl. Aromat. Comp. 2014, 34, 35-53. [CrossRef]

12. Kucharski, J.; Wieczorek, K.; Wyszkowska, J. Changes in the enzymatic activity in sandy loam soil exposed to zinc pressure. J. Elem. 2011, 16, 577-589. [CrossRef]

13. Boros-Lajszner, E.; Wyszkowska, J.; Kucharski, J. Application of white mustard and oats in the phytostabilisation of soil contaminated with cadmium with the addition of cellulose and urea. J. Soil Sediment. 2019, 20, 931-942. [CrossRef]

14. Zaborowska, M.; Kucharski, J.; Wyszkowska, J. Biological activity of soil contaminated with cobalt, tin and molybdenum. Environ. Monit. Assess. 2016, 188, 398. [CrossRef] [PubMed]

15. Zaborowska, M.; Kucharski, J.; Wyszkowska, J. Brown algae and basalt meal in maintaining the activity of arylsulfatase of soil polluted with cadmium. Water Air Soil Pollut. 2017, 228, 267. [CrossRef] [PubMed]

16. Addorisio, V.; Pirozzi, D.; Esposito, S.; Sannino, F. Decontamination of waters polluted with simazine by sorption on mesoporous metal oxides. J. Hazard. Mater. 2011, 196, 242-247. [CrossRef]

17. Sannino, F.; Gianfreda, L. Pesticide influence on soil enzymatic activities. Chemosphere 2001, 45, 417-425. [CrossRef]

18. Prieto, M.J.; Acevedo, S.O.A.; Prieto, G.F.; González, N.T. Phytoremediation of soils contaminated with heavy metals. Biodiversity Int. J. 2018, 2, 362-376. [CrossRef]

19. Gałązka, A.; Gałązka, R. Phytoremediation of polycyclic aromatic hydrocarbons in soils artificially polluted using plant-associated-endophytic bacteria and Dactylis glomerata as the bioremediation plant. Pol. J. Microbiol. 2015, 64, 241-252. [CrossRef] [PubMed]

20. Xu, X.; Liu, W.; Tian, S.; Wang, W.; Qi, Q.; Jiang, P.; Gao, X.; Li, F.; Li, H.; Yu, H. Petroleum hydrocarbon-degrading bacteria for the remediation of oil pollution under aerobic conditions: A perspective analysis. Water Air Soil Pollut. 2018, 9, 2885. [CrossRef] [PubMed]

21. Yan, S.; Wang, Q.; Qu, L.; Li, C. Characterization of oil-degrading bacteria from oil-contaminated soil and activity of their enzymes. Biotechnol. Biotechnol. Equip. 2013, 27, 3932-3938. [CrossRef]

22. Borowik, A.; Wyszkowska, J. Bioaugmentation of soil contaminated with diesel oil. J. Elem. 2018, 23, 1161-1178. [CrossRef]

23. Wolińska, A.; Gałązka, A.; Kuźniar, A.; Goraj, W.; Jastrzębska, N.; Grządziel, J.; Stępniewska, Z. Catabolic fingerprinting and diversity of bacteria in mollic gleysol contaminated with petroleum substances. Appl. Sci. 2018, 8, 1970. [CrossRef]

24. Yang, R.; Zhang, G.; Li, S.; Moazeni, F.; Li, Y.; Wu, Y.; Zhang, W.; Chen, T.; Liu, G.; Zhang, B.; et al. Degradation of crude oil by mixed cultures of bacteria isolated from the Qinghai-Tibet plateau and comparative analysis of metabolic mechanisms. Environ. Sci Pollut Res. 2018, 26, 1834-1847. [CrossRef] [PubMed]

25. Patowary, K.; Patowary, R.; Kalita, M.C.; Deka, S. Development of an efficient bacterial consortium for the potential remediation of hydrocarbons from contaminated sites. Front. Microbiol. 2016, 7, 1092. [CrossRef]

26. Obi, L.U.; Atagana, H.I.; Adeleke, R.A. Isolation and characterisation of crude oil sludge degrading bacteria. Springer Plus 2016, 5, 1946. [CrossRef]

27. Ibrahim, M.L.; Ijah, U.J.J.; Manga, S.B.; Bilbis, L.S.; Umar, S. Production and partial characterization of biosurfactant produced by crude oil degrading bacteria. Int. Biodeter Biodegr. 2013, 81, 28-34. [CrossRef]

28. Chandankere, R.; Yao, J.; Cai, M.; Masakorala, K.; Jain, A.K.; Choi, M.M.F. Properties and characterization of biosurfactant in crude oil biodegradation by bacterium Bacillus methylotrophicus USTBa. Fuel 2014, 122, 140-148. [CrossRef]

29. Wyszkowska, J.; Borowik, A.; Kucharski, J. The resistance of Lolium perenne L. $\times$ hybridum, Poa pratensis, Festuca rubra, F. arundinacea, Phleum pratense and Dactylis glomerata to soil pollution by diesel oil and petroleum. Plant Soil Environ. 2019, 65, 307-312. [CrossRef] 
30. Goncharov, A.A.; Tiunov, A.V. Trophic chains in the soil. Trophic chains in the soil. Biol. Bull. Rev. 2014, 4, 393-403. [CrossRef]

31. Kucharski, J.; Jastrzebska, E. Effects of heating oil on the count of microorganisms and physico-chemical properties of soil. Polish J. Environ. Stud. 2005, 14, 195-204.

32. International Energy Agency (IEA). Oil Market Report; International Energy Agency: Paris, France, $2019 ;$ p. 55.

33. Kiamarsi, Z.; Soleimani, M.; Nezami, A.; Kafi, M. Biodegradation of n-alkanes and polycyclic aromatic hydrocarbons using novel indigenous bacteria isolated from contaminated soils. Int. J. Environ. Sci. Technol. 2019, 16, 6805-6816. [CrossRef]

34. Nedaa, A.; Dashti, N.; Khanafer, M.; Husain, A.A.; Samir, R. Bioremediation of soils saturated with spilled crude oil. Sci. Rep. 2020, 10, 1-9. [CrossRef]

35. Borowik, A.; Wyszkowska, J. Remediation of soil contaminated with diesel oil. J. Elem. 2018, 23, 767-788. [CrossRef]

36. Fatima, K.; Imran, A.; Amin, I.; Khan, Q.M.; Afzal, M. Successful phytoremediation of crude-oil contaminated soil at an oil exploration and production company by plants-bacterial synergism. Int. J Phytoremediat. 2018, 20, 675-681. [CrossRef]

37. Iqbal, A.; Mukherjee, M.; Rashid, J.; Khan, S.A.; Ali, M.A.; Arshad, A. Development of plant-microbe phytoremediation system for petroleum hydrocarbon degradation: An insight from alkb gene expression and phytotoxicity analysis. Sci. Total Environ. 2019, 671, 696-704. [CrossRef] [PubMed]

38. Agnello, A.C.; Bagard, M.; van Hullebusch, E.D.; Esposito, G.; Huguenot, D. Comparative bioremediation of heavy metals and petroleum hydrocarbons co-contaminated soil by natural attenuation, phytoremediation, bioaugmentation and bioaugmentation-assisted phytoremediation. Sci. Total Environ. 2016, 563-564, 693-703. [CrossRef]

39. Estendorfer, J.; Stempfhuber, B.; Haury, P.; Vestergaard, G.; Rillig, M.C.; Joshi, J.; Schröder, P.; Schloter, M. The influence of land use intensity on the plant-associated microbiome of Dactylis glomerata L. Front. Plant Sci. 2017, 8, 930. [CrossRef]

40. Mika, V.; Kohoutek, A.; Odstrcilova, V. Characteristics of important diploid and tetraploid subspecies of Dactylis from poInt. of view of the forage crop production. Rostl. Vyroba 2002, 48, 243-248. [CrossRef]

41. Paliwa, B.P. Available online: https://www.bp.com/pl_pl/poland/home/produkty_uslugi/paliwa.html (accessed on 30 March 2020).

42. Statistical Report 2019. FuelsEurope 2019, 1-68. Available online: https://www.fuelseurope.eu/wp-content/ uploads/FuelsEurope-Statistical-Report-2019-2.pdf (accessed on 23 March 2020).

43. Sanderson, M.A.; Skinner, R.H.; Elwinger, G.F. Seedling development and field performance of prairiegrass, grazing bromegrass, and orchard grass. Crop Sci. 2002, 42, 224-230. [CrossRef]

44. Kaimi, E.; Mukaidani, T.; Miyoshi, S.; Tamaki, M. Ryegrass enhancement of biodegradation in diesel-contaminated soil. Environ. Exp. Bot. 2006, 55, 110-119. [CrossRef]

45. Ruley, J.A.; Tumuhairwe, J.B.; Amoding, A.; Opolot, E.; Oryem-Origa, H.; Basamba, T. Assessment of plants for phytoremediation of hydrocarbon-contaminated soils in the Sudd Wetland of South Sudan. Plant Soil Environ. 2019, 65, 463-469. [CrossRef]

46. Borowik, A.; Wyszkowska, J.; Wyszkowski, M. Resistance of aerobic microorganisms and soil enzyme response to soil contamination with Ekodiesel Ultra fuel. Environ. Sci. Pollut. Res. 2017, 24, 24346-24363. [CrossRef] [PubMed]

47. Öhlinger, R. Dehydrogenase activity with the substrate TTC. In Methods in Soil Biology; Schinner, F., Öhlinger, R., Kandler, E., Margesin, R., Eds.; Springer: Berlin, Germany, 1996; pp. 241-243.

48. Alef, K.; Nannipieri, P. Methods in Applied Soil Microbiology and Biochemistry; Alef, K., Nannipieri, P., Eds.; Academic Press: Cambridge, MA, USA, 1998; pp. 316-365.

49. Johnson, J.I.; Temple, K.L. Some variables affecting the measurement of catalase activity in soil. Soil Sci. Soc. Am. Pro. 1964, 28, 207-216. [CrossRef]

50. ISO 18287. In Soil Quality—Determination of Polycyclic Aromatic Hydrocarbons (PAH)—Gas Chromatographic Method with Mass Spectrometric Detection (GC-MS); International Organization for Standardization: Geneva, Switzerland, 2006.

51. EN ISO 16703. In Soil Quality-Determination of Content of Hydrocarbon in the Range $C_{10}$ to $C_{40}$ by Gas Chromatography; International Organization for Standardization: Geneva, Switzerland, 2004. 
52. EN ISO 22155. In Soil Quality-Gas Chromatographic Determination of Volatile Aromatic and Halogenated Hydrocarbons and Selected Ethers—Static Headspace Method; International Organization for Standardization: Geneva, Switzerland, 2016.

53. Nelson, D.W.; Sommers, L.E. Total carbon, organic carbon, and organic matter. In Method of Soil Analysis; Sparks, D.L., Ed.; Chemical Methods, American Society of Agronomy: Madison, WI, USA, 1996; pp. 1201-1229.

54. ISO 11261. In Soil Quality-Determination of Total Nitrogen-Modified Kjeldahl Method; International Organization for Standardization: Geneva, Switzerland, 1995.

55. Egner, H.; Riehm, H.; Domingo, W.R. Untersuchungen über diechemische Bodenanalyse als Grundlage für die Beurteilung des Nährstoffzustandes der Böden. II. Chemische Extractions methoden zur Phosporund Kaliumbestimmung. Ann. R. Agric. Coll. Swed. 1960, 26, 199-215.

56. Schlichting, E.; Blume, H.P.; Stahr, K. Bodenkundliches Praktikum. In Pareys Studientexte; Auflage, 295 S.; Blackwell Wissenschafts-Verlag: Berlin, Germany, 1995; Volume 81, p. 2.

57. PN-R-04032. In Soil and MINERAL materials-Sampling and Determination of Particle Size Distribution; Polish Committee for Standardization: Warsaw, Poland, 1998.

58. ISO 11464. In Soil Quality_Pre-Treatment of Samples for Physico-Chemical Analysis; International Organization for Standardization: Geneva, Switzerland, 2006.

59. ISO 10390. In Soil Quality—Determination of $p H$; International Organization for Standardization: Geneva, Switzerland, 2005.

60. Klute, A. Methods of Soil Analysis; American Society of Agronomy, Agronomy Monograph 9: Madison, WI, USA, 1996.

61. De Leij, F.A.A.M.; Whipps, J.M.; Lynch, J.M. The use of colony development for the characterization of bacterial communities in soil and on roots. Microb. Ecol. 1993, 27, 81-97. [CrossRef]

62. Parks, D.H.; Tyson, G.W.; Hugenholtz, P.; Beiko, R.G. STAMP: Statistical analysis of taxonomic and functional profiles. Bioinformatics 2014, 30, 3123-3124. [CrossRef]

63. RStudio Team. RStudio: Integrated Development for R; RStudio, Inc.: Boston, MA, USA, 2019; Available online: http://www.rstudio.com/ (accessed on 23 February 2020).

64. R Core Team. R: A Language and Environment for Statistical Computing; R Foundation for Statistical Computing: Vienna, Austria, 2019; Available online: https://www.R-project.org/ (accessed on 23 February 2020).

65. Gregory, R.W.; Bolker, B.; Bonebakker, L.; Gentleman, R.; Liaw, W.H.A.; Lumley, T.; Maechler, M.; Magnusson, A.; Moeller, S.; Schwartz, M.; et al. gplots: Various R Programming Tools for Plotting Data; R Package Version 2.17.0. 2020. Available online: https:/CRAN.R-project.org/package=gplots (accessed on 23 February 2020).

66. Orwin, K.H.; Wardle, D.A. New indices for quantifying the resistance and resilience of soil biota to exogenous disturbances. Soil Biol. Biochem. 2004, 36, 1907-1912. [CrossRef]

67. Dell Inc. Dell Statistica (Data Analysis Software System), Version 13.1; Dell Inc.: Tulsa, OK, USA, 2016.

68. Gu, Y.; Wang, Y.; Lu, S.; Xiang, Q.; Yu, X.; Zhao, K.; Zou, L.; Chen, Q.; Tu, S.; Zhang, X. Long-term fertilization structures bacterial and archaeal communities along soil depth gradient in a paddy soil. Front. Microbiol. 2017, 8, 1516. [CrossRef]

69. Kumar, V.; AlMomin, S.; Al-Aqeel, H.; Al-Salameen, F.; Nair, S.; Shajan, A. Metagenomic analysis of rhizosphere microflora of oil-contaminated soil planted with barley and alfalfa. PLoS ONE 2018, 13, e0202127. [CrossRef]

70. Gałązka, A.; Grządziel, J.; Gałązka, R.; Ukalska-Jaruga, A.; Strzelecka, J.; Smreczak, B. Genetic and functional diversity of bacterial microbiome in soils with long term impacts of petroleum hydrocarbons. Front. Microbiol. 2018, 9, 1923. [CrossRef] [PubMed]

71. Delgado-Baquerizo, M.; Oliverio, A.M.; Brewer, T.E.; Benavent-González, A.; Eldridge, D.J.; Bardgett, R.D.; Maestre, F.T.; Singh, B.K.; Fierer, N.A. Global atlas of the dominant bacteria found in soil. Science 2018, 359, 320-325. [CrossRef] [PubMed]

72. Wemheuer, F.; Kaiser, K.; Karlovsky, P.; Daniel, R.; Vidal, S.; Wemheuer, B. Bacterial endophyte communities of three agricultural important grass species differ in their response towards management regimes. Sci Rep. 2017, 7, 40914. [CrossRef] [PubMed]

73. Islam, Z.F.; Cordero, P.R.F.; Feng, J.; Chen, Y.-J.; Bay, S.K.; Jirapanjawat, T.; Gleadow, R.M.; Carere, C.R.; Stott, M.B.; Chiri, E.; et al. Two Chloroflexi classes independently evolved the ability to persist on atmospheric hydrogen and carbon monoxide. ISME J. 2019, 13, 1801-1813. [CrossRef] 
74. DeBruyn, J.M.; Nixon, L.T.; Fawaz, M.N.; Johnson, A.M.; Radosevich, M. Global biogeography and quantitative seasonal dynamics of Gemmatimonadetes in soil. Appl. Environ. Microbiol. 2011, 70, 6295-6300. [CrossRef]

75. de León-Lorenzana, A.S.; Delgado-Balbuena, L.; Domínguez-Mendoza, C.; Navarro-Noya, Y.E.; Luna-Guido, M.; Dendooven, L. Reducing salinity by flooding an extremely alkaline and saline soil changes the bacterial community but its effect on the archaeal community is limited. Front. Microbiol. 2017, 8 , 466. [CrossRef]

76. Raju, M.N.; Leo, R.; Herminia, S.S.; Morán, R.E.; Venkateswarlu, K.; Laura, S. Biodegradation of diesel, crude oil and spent lubricating oil by soil isolates of Bacillus spp. Bull Environ Contam Toxicol. 2017, 98, 698-705. [CrossRef]

77. Mukherjee, A.; Chettri, B.; Langpoklakpam, J.S.; Basak, P.; Prasad, A.; Mukherjee, A.K.; Bhattacharyya, M.; Singh, A.K.; Chattopadhyay, D. Bioinformatic approaches including predictive metagenomic profiling reveal characteristics of bacterial response to petroleum hydrocarbon contamination in diverse environments. Sci. Rep. 2017, 7, 1108. [CrossRef]

78. Røberg, S.; Østerhus, J.I.; Landfald, B. Dynamics of bacterial community exposed to hydrocarbons and oleophilic fertilizer in high-arctic intertidal beach. Polar Biol. 2011, 34, 1455-1465. [CrossRef]

79. Hemkemeyer, M.; Dohrmann, A.B.; Christensen, B.T.; Tebbe, C.C. Bacterial preferences for specific soil particle size fractions revealed by community analyses. Front. Microbiol. 2018, 9, 149. [CrossRef]

80. Telesiński, A.; Krzyśko-Łupicka, T.; Cybulska, K.; Pawłowska, B.; Biczak, R.; Śnieg, M.; Wróbel, J. Comparison of oxidoreductive enzyme activities in three coal tar creosote-contaminated soils. Soil Res. 2019, 57, 814-824. [CrossRef]

81. Lipińska, A.; Kucharski, J.; Wyszkowska, J. Activity of arylsulphatase in soil contaminated with polycyclic aromatic hydrocarbons. Water Air Soil Pollut. 2014, 225, 2097. [CrossRef] [PubMed]

82. Wolińska, A.; Kuźniar, A.; Szafranek-Nakonieczna, A.; Jastrzębska, N.; Roguska, E.; Stępniewska, Z. Biological activity of autochthonic bacterial community in oil-contaminated soil. Water Air Soil Pollut. 2016, 227, 130. [CrossRef] [PubMed]

83. Lipińska, A.; Kucharski, J.; Wyszkowska, J. Activity of phosphatases in soil contaminated with PAHs. Water Air Soil Pollut. 2019, 230, 298. [CrossRef]

84. Wyszkowska, J.; Kucharski, M.; Kucharski, J. Application of the activity of soil enzymes in the evaluation of soil contamination by diesel oil. Polish J. Environ. Stud. 2006, 15, 501-506. Available online: http://www.pjoes.com/Application-of-the-Activity-of-Soil-Enzymes-in-the-Evaluation-ofSoil-Contamination, 87896,0,2.html (accessed on 23 March 2020).

85. Xiaoyan, Z.; Xianghua, W.; Yan, F. Influence of glucose feeding on the ligninolytic enzyme production of the white-rot fungus Phanerochaete chrysosporium. Front. Environ. Sci. Eng. China 2007, 1, 89-94. [CrossRef]

86. Chen, R.; Senbayram, M.; Blagodatsky, S.; Myachina, O.; Dittert, K.; Lin, X.; Blagodatskaya, E.; Kuzyakov, Y. Soil $\mathrm{C}$ and $\mathrm{N}$ availability determine the priming effect: Microbial $\mathrm{N}$ mining and stoichiometric decomposition theories. Glob. Chang. Biol. 2014, 20, 2356-2367. [CrossRef]

87. Liu, X.; Li, Z.; Zhang, C.; Tan, X.; Yang, X.; Wan, C.; Lee, D.J. Enhancement of anaerobic degradation of petroleum hydrocarbons by electron intermediate: Performance and mechanism. Bioresour. Technol. 2020, 295, 122305. [CrossRef]

88. Gianfreda, L. Enzymes of importance to rhizosphere processes. J. Soil Sci. Plant Nut. 2015, 15, $283-306$. [CrossRef]

89. Duly, O.; Nannipieri, P. Intracellular and extracellular enzyme activity in soil with reference to elemental cycling. Zeitschrift für Pflanzenernährung und Bodenkunde 1998, 161, 243-248. [CrossRef]

90. Burns, R.G.; DeForest, J.L.; Marxsen, J.; Sinsabaugh, R.L.; Stromberger, M.E.; Wallenstein, M.D.; Weintraub, M.N.; Zoppini, A. Soil enzymes in a changing environment: Current knowledge and future directions. Soil Biol. Biochem. 2013, 58, 216-234. [CrossRef]

91. Sarma, H.; Nava, A.R.; Prasad, M.N.V. Mechanistic understanding and future prospect of microbe-enhanced phytoremediation of polycyclic aromatic hydrocarbons in soil. Environ. Technol. Inno. 2018, 13, 318-330. [CrossRef]

92. Hou, L.; Liu, R.; Li, N.; Dai, Y.; Yan, J. Study on the efficiency of phytoremediation of soils heavily polluted with PAHs in petroleum-contaminated sites by microorganism. Environ. Sci Pollut Res. 2019, 26, 31401-31413. [CrossRef] [PubMed] 
93. Placek, A.; Grobelak, A.; Kacprzak, M. Improving the phytoremediation of heavy metals contaminated soil by use of sewage sludge. Int. J. Phytoremediat. 2015, 18, 605-618. [CrossRef] [PubMed]

94. Liu, H.; Tan, X.; Guo, J.; Liang, X.; Xie, Q.; Chen, S. Bioremediation of oil-contaminated soil by combination of soil conditioner and microorganism. J Soils Sediments 2020, 20, 2121-2129. [CrossRef]

95. An, D.; Brown, D.; Chatterjee, I.; Dong, X.; Ramos-Padron, E.; Wilson, S.; Bordenave, S.; Caffrey, S.M.; Gieg, L.M.; Sensen, C.W. Microbial community and potential functional gene diversity involved in anaerobic hydrocarbon degradation and methanogenesis in an oil sands tailings pond. Genome 2013, 56, 612-618. Available online: https://www.nrcresearchpress.com/doi/full/10.1139/gen-2013-0083\# .Xleb0dThDGg (accessed on 23 March 2020). [CrossRef]

96. Chukwuma, C.; Ikewuchi, J.; Monanu, M. Removal of hydrocarbons from crude oil contaminated agricultural soil by phytoremediation using Mariscus alternifolius and Fimbristylis ferruginea. Eur. J. Biol. Res. 2019, 9, 34-44. [CrossRef]

97. Cheng, L.; Zhou, Q.; Yu, B. Responses and roles of roots, microbes, and degrading genes in rhizosphere during phytoremediation of petroleum hydrocarbons contaminated soil. Int. J. Phytoremediat. 2019, 21, 1161-1169. [CrossRef]

98. Hunt, L.J.; Duca, D.; Dan, T.; Knopper, L.D. Petroleum hydrocarbon (PHC) uptake in plants: A literature review. Environ. Pollution. 2019, 245, 472-484. [CrossRef]

99. Sandermann, H. Higher plant metabolism of xenobiotics: The 'green liver' concept. Pharmacogenetics 1994, 4, 225-241. [CrossRef]

100. Jing, W.; Xinying, Z.; Xiaoyan, L.; Xia, L.; Xueping, C. Influence of root components of celery on pyrene bioaccessibility, soil enzymes and microbial communities in pyrene and pyrene-diesel spiked soils. Sci. Total Environ. 2017, 599-600, 50-57. [CrossRef]

101. Al-Mailem, D.M.; Kansour, M.K.; Radwan, S.S. Cross-bioaugmentation among four remote soil samples contaminated with oil exerted just inconsistent effects on oil-bioremediation. Front. Microbiol. 2019, 10, 2827. [CrossRef] [PubMed]

(C) 2020 by the authors. Licensee MDPI, Basel, Switzerland. This article is an open access article distributed under the terms and conditions of the Creative Commons Attribution (CC BY) license (http://creativecommons.org/licenses/by/4.0/). 